\title{
Keterampilan Berkomunikasi dan Berkolaborasi untuk Mempersiapkan Lulusan Siswa SMK
}

\author{
Rico Andhika Putra ${ }^{1}$, Widiyanti ${ }^{2}$, Eddy Sutadji ${ }^{2}$ \\ ${ }^{1}$ Pendidikan Kejuruan-Universitas Negeri Malang \\ ${ }^{2}$ Teknik Mesin-Universitas Negeri Malang
}

\begin{tabular}{l}
\hline \hline INFO ARTIKEL \\
\hline Riwayat Artikel: \\
Diterima: $11-04-2020$ \\
Disetujui: $11-08-2020$ \\
\hline
\end{tabular}

\section{Kata kunci:}

communication skills;

collaborating skills;

working readiness;

keterampilan berkomunikasi,

keterampilan berkolaborasi;

kesiapan kerja

\begin{abstract}
This research was conducted with the aim to determine the effect of communication and collaboration skills on vocational students' work readiness. The number of research respondents was 114 students. Research Instrumens using Instrumens that have been used, namely Self-Perceived Communication Competence Scale, Teamwork Scale for Youth, Work Readiness Scale. The results found that communication and collaborative skills have an influence on student work readiness simultaneously and partially. Increasing these skills will increase the vocational students' work readiness. In schools that play a role in improving communication and collaboration skills is the teacher, if outside the school the role is parents with regular supervision processes.

Abstrak: Penelitian ini dilaksanakan dengan tujuan untuk mengetahui pengaruh keterampilan berkomunikasi dan berkolaborasi terhadap kesiapan kerja siswa SMK. Responden penelitian berjumlah 114 siswa. Instrumen penelitian menggunakan instrumen yang sudah pernah digunakan yaitu Self-Perceived Communication Competence Scale, Teamwork Scale for Youth, Work Readiness Scale. Hasil penelitian didapatkan bahwa keterampilan berkomunikasi dan berkolaborasi memiliki pengaruh dalam kesiapan kerja siswa secara simultan dan parsial. Semakin meningkatkanya keterampilan tersebut maka semakin meningkat dalam kesiapan kerja siswa SMK. Dalam sekolah yang berperan dalam meningkatkan keterampilan komunikasi dan kolaborasi adalah guru, jika berada di luar sekolah yang berperan adalah orang tua dengan proses pengawasan secara berkala.
\end{abstract}

ABSTRAK

\author{
Alamat Korespondensi: \\ Rico Andhika Putra \\ Pendidikan Kejuruan \\ Universitas Negeri Malang \\ Jalan Semarang 5 Malang \\ E-mail: ricoandhika55@gmail.com
}

Perkembangan dunia industri dan dunia usaha semakin cepat dan mengharapkan seluruh sumber daya manusia mampu mengikuti. Berkenaan dengan perkembangan tersebut, pihak industri memerlukan sumber daya manusia yang terampil, berwawasan luas dan mampu bersaing (Putri, Effendi, \& Slamet 2019; Turistiati \& Ramadhan 2019). Seorang individu yang memiliki daya bersaing tinggi merupakan kebutuhan mutlak di dunia industri (Manyi, Sibanda, \& Katrodia 2018; Sihite 2018). Kekurangan keterampilan lain yang diharapkan pihak industri masih menjadi suatu permasalahan, dengan adanya keterampilan lain di luar bidang keahlian akan mempermudah pihak industri lebih mudah untuk melaksanakan pekerjaannya. Tidak hanya lulusan dari sekolah kejuruan yang harus mempersiapkan keterampilan lain, karyawan yang sudah bekerja harus mempersiapkan juga (Alvarez, Gillies, \& Bradsher 2003; Casner-Lotto \& Barrington 2006; Soulé \& Warrick 2015). Untuk menjadi seorang pekerja harus mampu memiliki keterampilan lain untuk meningkatkan dunia perindustrian di Indonesia, sehingga kualitas dari sumber daya manusia tidak hanya di lihat dari kemampuan pada bidangnya. Rendahnya tingkat pendidikan yang berdampak pada kurangnya keterampilan seorang pekerja akan berdampak pada meningkatnya pengangguran (Aprianto \& Khairrunnisa 2013; Sari, Putro, \& Novalia 2015). Sekolah Menengah Kejuruan termasuk salah satu solusi pada permasalahan tentang pengangguran, lulusan dari SMK sudah dibekali dengan karakter beserta keterampilan pada bidangnya untuk memasuki dunia industri (Titin, 2016).

Keterampilan lain yang perlu ditingkatkan adalah keterampilan berkomunikasi dan berkolaborasi. Kebutuhan dalam lulusan siswa SMK untuk memasuki dunia industri selain keterampilan yang sudah dimiliki pada bidangnya adalah keterampilan dalam berkomunikasi (Wahyuni, Masih, \& Mei Rejeki 2018). Keterampilan berkomunikasi menjadi salah satu kebutuhan siswa SMK untuk mempersiapkan memasuki jenjang yang lebih tinggi (Lukyanova, Daneykin, \& Daneikina 2015). Proses komunikasi di tempat kerja bertujuan untuk membangun dan mempertahankan sebuah hubungan kerja yang berkualitas dan meningkatkan kualitas kinerja pada bidangnya (Adu-Oppong and Agyin-Birikorang 2014; Doyle 2017). 
Untuk memperkuat keterampilan berkomunikasi diimbangi dengan keterampilan berkolaborasi atau kerja tim. Semakin tinggi keterampilan untuk bekerja sama akan lebih mudah untuk mendapatkan pekerjaan dan akan menjadi tenaga kerja yang akan dicari pada abad 21 (Reevy, Chamberlain, \& Stein 2013). Keterampilan bekerja sama akan menjadi keterampilan yang akan selalu dibutuhkan pada pekerjaan apapun saat melakukan pekerjaan pada bidang apapun (Belgrad, Fisher, \& Rayner 1995). Pernyataan tersebut dibenarkan pada saat melakukan observasi pada BKK SMK di Kabupaten Tulungagung bahwa siswa yang memiliki kemampuan berkolaborasi mampu mencari kerja dengan baik dan bisa diterima di pekerjaan yang dipilih sebelumnya. Proses bekerja tim mampu meningkatkan produktivitas sebuah perusahaan (Alghamdi and Bach 2018). Pada proses pembelajaran diharapkan guru menggunakan pembelajaran secara kolaboratif sehingga siswa mampu meningkatkan kemampuan dalam bekerja sama (Harefa \& Suyanti 2019). Kolaborasi menekankan adanya prinsip-prinsip kerja (Suryadi, 2010). Secara garis besar, prinsip tersebut mengajarkan bahwa dalam berkolaborasi tidak mementingkan keinginan sendiri dan mampu mengerjakan secara bersama untuk mencapai tujuan bersama.

Keterampilan ini diperoleh dengan berbagai cara, tetapi cara yang efektif dan mudah dengan berkomunikasi dan berkolaborasi antar kelompok. Terbentuknya suatu kolaborasi yang baik dalam suatu kelompok maka peran pendidik, yaitu (1) berorientasi pada tujuan dan sasaran proses pembelajaran, (2) menyusun sebuah keputusan tentang durasi bekerja secara kelompok, (3) menyusun tugas untuk melengkapi proses pembelajaran, dan (4) memastikan antar kelompok berperan secara aktif (Barkley, Cross, \& Major 2004).

Terpenuhnya keterampilan lain yang dimiliki seorang siswa akan mempermudah siswa tersebut menerima tuntutan pada perkembangan zaman yang semakin meningkat. Tuntutan kerja pada perkembangan zaman akan semakin berkembang dan proses berkembangnya harus diiringi dengan tenaga kerjanya sehingga dapat menyelaraskan dengan kondisi yang sedang berjalan. Selain tuntutan sebagai tenaga kerja profesional, seorang siswa kejuruan harus mampu menjadi pribadi yang mandiri melalui keterampilan berwirausaha sehingga siswa mampu bertahan dalam kehidupan selanjutnya. Pelaksanaan penelitian ini bertujuan untuk melihat pengaruh keterampilan berkomunikasi dan keterampilan berkolaborasi terhadap kesiapan kerja siswa SMK. Proses penelitian diharapkan dapat menjadi referensi atau rujukan dalam pengembangan keterampilan selain keterampilan bidang keahlian yang telah dipelajari oleh siswa SMK.

\section{METODE}

Penelitian yang dilakukan menggunakan penelitian jenis kuantitatif. Variabel dependen yang terdapat dalam penelitian ini adalah kesiapan kerja dan variabel independennya adalah keterampilan berkomunikasi dan keterampilan berkolaborasi. Penelitian ini dilaksanakan di SMK Veteran 1 Tulungagung.

Populasi penelitian ini adalah siswa kelas XII di SMK Veteran 1 Tulungagung dengan jumlah 225 siswa dan dengan jumlah kelas sebanyak enam kelas. Proses pengambilan sampel menggunakan rumus Slovin dengan signifikansi sebesar 5\%. Jumlah populasi di setiap kelas memiliki jumlah yang berbeda-beda, untuk mempermudah dalam penyebaran kuesioner setiap kelas maka proses penyebaran menggunakan teknik proportional random sampling. Dengan pengambilan sampel tersebut didapatkan sampel sejumlah 144 responden untuk mengisi kuesioner yang telah disediakan.

Teknik pengumpulan data pada penelitian ini adalah penyebaran kuesioner. Kuesioer yang digunakan merupakan instrumen yang pernah digunakan dalam penelitian sebelumnya. Proses penilaian pada variabel keterampilan berkomunikasi menggunakan instrumen Self-Perceived Communication Competence Scale (McCroskey \& McCroskey 1988), hasil dari penggunaan instrumen didukung oleh penelitian yang dilakukan (Shahbaz et al. 2016). SPCC berjumlah 12 butir. Instrumen Teamwork Scale for Youth digunakan untuk mengukur atau melakukan proses penilaian pada variabel keterampilan berkolaborasi (Lower, Newman, and Anderson-Butcher 2015). Instrumen Teamwork Scale for Youth berjumlah delapan butir. Pada variabel kesiapan kerja menggunakan instrumen Work Readiness Scale dengan jumlah item sebanyak 64 butir. Instrumen ini diambil dalam penelitian yang dilakukan oleh Walker, Storey, Costa, \& Leung (2015). Analisis regresi linier berganda digunakan untuk pengujian pada penelitian ini yaitu untuk mengetahui pengaruh yang terjadi dalam variabel dependen akibat pengaruh dari variabel independen secara parsial dan simultan.

\section{HASIL \\ Deskripsi Data}

Hasil penelitian yang dibahas dan diuraikan antara lain adalah (1) keterampilan berkomunikasi; (2) keterampilan berkolaborasi; (3) kesiapan kerja. Penilaian dari tiga variabel tersebut merupakan hasil dari kuesioner yang diisi oleh siswa yang menjadi sampel pada penelitian ini.

Variabel keterampilan berkomunikasi diukur menggunakan kuesioner dengan jumlah 12 butir. Nilai rata-rata pada variabel ini 36,10, nilai standar deviasi sebesar 5,56, nilai terendah dan tertinggi sebesar 15 dan 47 . Deskripsi frekuensi dari variabel keterampilan berkomunikasi terdapat pada gambar 1. Dari hasil gambar 1 dapat diuraikan sebagai berikut, siswa yang memiliki kriteria sangat rendah bernilai sebesar $1.5 \%$, pada kriteria rendah bernilai sebesar 3.5\%, pada kriteria tinggi bernilai sebesar $66 \%$, dan pada kriteria sangat tinggi bernilai sebesar 29\%. Sesuai hasil analisis deskripsi, kriteria keterampilan berkomunikasi siswa SMK Veteran 1 Tulungagung dapat dikategorikan tinggi. 


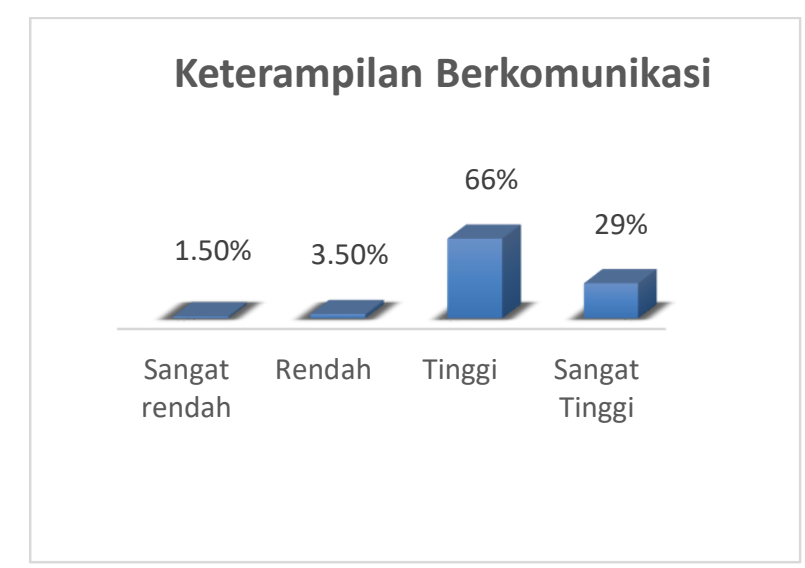

\section{Gambar 1. Diagram Frekuensi Variabel Keterampilan Berkomunikasi}

Pada variabel bebas ke dua adalah variabel keterampilan berkolaborasi diukur menggunakan kuesioner dengan jumlah sebanyak delapan butir. Nilai rata-rata pada variabel ini 24,14, nilai standar deviasi sebesar 3,52, nilai terendah sebesar 16, dan nilai tertinggi sebesar 32. Deskripsi frekuensi dari variabel keterampilan berkolaborasi terdapat pada gambar 2. Dari hasil gambar 2 dapat diuraikan sebagai berikut, siswa berada pada kriteria sangat rendah bernilai sebesar 0\%, pada kriteria rendah bernilai sebesar 26\%, pada kriteria tinggi bernilai sebesar 65\%, dan pada kriteria sangat tinggi bernilai sebesar 9\%. Sesuai hasil analisis deskripsi, kriteria keterampilan berkolaborasi siswa SMK Veteran 1 Tulungagung dapat dikategorikan tinggi.

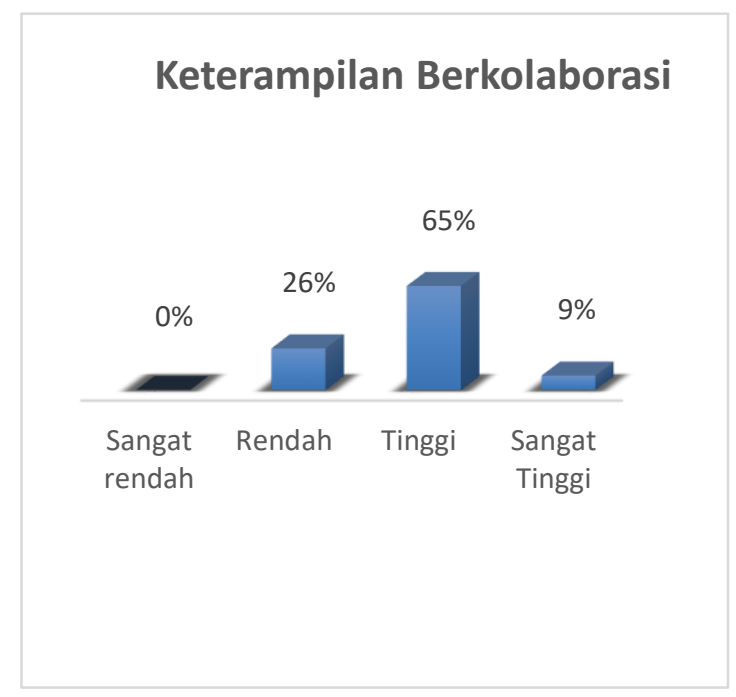

\section{Gambar 2. Diagram Frekuensi Variabel Keterampilan Berkolaborasi}

Variabel kesiapan kerja di ukur menggunakan kuesioner yang dengan jumlah sebanyak 64 butir. Nilai rata-rata pada variabel ini 177,48, nilai standar deviasi sebesar 18,06, nilai terendah sebesar 134, dan nilai tertinggi sebesar 213. Deskripsi frekuensi dari variabel kesiapan kerja terdapat pada gambar 3. Berdasarkan hasil diagram pada gambar 3 dapat diuraikan (1) siswa berada pada kriteria sangat rendah bernilai sebesar $0 \%$, (2) kriteria rendah bernilai sebesar $22.9 \%$, (3) kriteria tinggi bernilai sebesar $72.2 \%$, dan (4) kriteria sangat tinggi bernilai sebesar 49\%. Sesuai hasil analisis deskripsi, kriteria kesiapan kerja siswa SMK Veteran 1 Tulungagung dikategorikan tinggi. 


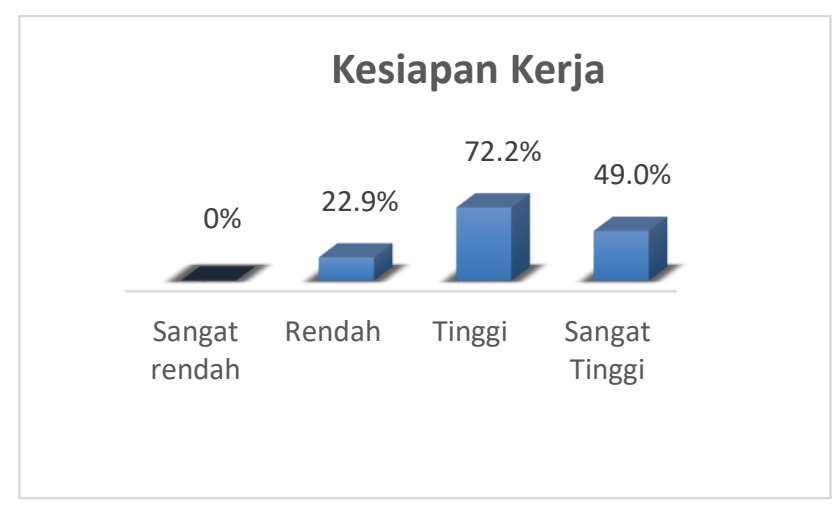

Gambar 3. Diagram Frekuensi Variabel Kesiapan Kerja

\section{Analisis Determinasi}

Hasil determinasi digunakan untuk melihat nilai pengaruh dari variabel independen terhadap variabel dependen. Jumlah nilai pengaruh antar variabel dapat dilihat pada nilai adjusted R Square pada hasil analisis regresi pada bagian tabel model summary. Hasil analisis determinasi secara parsial maupun simultan disajikan pada tabel 1.

Tabel 1. Hasil Analisis Determinasi Keterampilan Berkomunikasi terhadap Kesiapan Kerja

\begin{tabular}{lccccc}
\multicolumn{5}{c}{ Model Summary } \\
\hline Variabel & Model & $\mathbf{R}$ & R Square & $\begin{array}{c}\text { Adjusted } \\
\text { R Square }\end{array}$ & $\begin{array}{c}\text { Std. Error of } \\
\text { the Estimate }\end{array}$ \\
\hline $\mathrm{X}^{1}-\mathrm{Y}$ & 1 & $.526^{\mathrm{a}}$ & .277 & .272 & 12.696 \\
$\mathrm{X}^{2}-\mathrm{Y}$ & 1 & .759 & .577 & .574 & 9.715 \\
$\mathrm{X}^{1} \mathrm{X}^{2}-\mathrm{Y}$ & 1 & .782 & .611 & .606 & 9.343 \\
\hline
\end{tabular}

Dari output Model Summary variabel $\mathrm{X}^{1}-\mathrm{Y}$ didapatkan nilai adjusted $R$ Square bernilai sebesar 0.277. Dari hasil output pada tabel determinasi bahwa persentase sumbangan bernilai sebesar $27.7 \%$. Pada variabel $\mathrm{X}^{2}-\mathrm{Y}$ didapatkan nilai adjusted $R$ Square sebesar 0.577 . Hal ini menunjukkan bahwa persentase sumbangan bernilai sebesar $57.7 \%$. variabel $\mathrm{X}^{1} \mathrm{X}^{2}-\mathrm{Y}$ didapatkan nilai adjusted $R$ Square sebesar 0.611. Hal ini menunjukkan bahwa persentase sumbangan dari dua variabel independen terhadap variabel dependen bernilai sebesar $61.1 \%$.

\section{Pengujian Hipotesis}

Persyaratan sebelum melakukan proses uji hipotesis adalah uji normalitas, uji linieritas, uji multikolinieritas, uji heteroskedastisitas, dan uji autokorelasi. Hasil uji prasyarat pada penelitian telah memenuhi syarat, sehingga bisa dilakukan uji hipotesis. Berdasarkan hasil uji F yang terdapat pada tabel 2 didapatkan F hitung bernilai sebesar 110.826 dengan menggunakan acuan $\mathrm{F}$ tabel sebesar dengan menggunakan acuan $\mathrm{F}$ tabel sebesar 3.06. Jika nila $\mathrm{F}$ hitung lebih besar dari nilai $\mathrm{F}$ tabel maka ada pengaruh secara bersama-sama antara variabel keterampilan berkomunikasi dan keterampilan berkolaborasi terhadap variabel kesiapan kerja.

Tabel 2. Hasil uji F

\begin{tabular}{llccccc}
\hline & Model & Sum of Squares & df & Mean Square & F & Sig. \\
\hline 1 & Regression & 19348.005 & 2 & 9674.003 & 110.826 & $.000^{\mathrm{b}}$ \\
& Residual & 12307.932 & 141 & 87.290 & & \\
& Total & 31655.937 & 143 & & & \\
\hline
\end{tabular}

a. Dependent Variable: Kesiapan_kerja

b. Predictors: (Constant), Kolaborasi, Komunikasi

Tabel 3. Hasil uji T

\begin{tabular}{ccccccc}
\hline \multicolumn{7}{c}{ Coefficients $^{\mathbf{a}}$} \\
& & \multicolumn{7}{c}{ Unstandardized CoefficientsStandardized Coefficients } & & \\
\cline { 3 - 6 } & & Model & B & Std. Error & Beta & Sig. \\
\hline 1 & (Constant) & 101.699 & 4.911 & & 20.709 & .000 \\
& Komunikasi & .482 & .136 & .212 & 3.539 & .001 \\
& Kolaborasi & 2.355 & .214 & .658 & 11.011 & .000 \\
\hline
\end{tabular}

a. Dependent Variable: Kesiapan_kerja 
Dari hasil uji T pada tabel 3 diperoleh data acuan nilai T tabel sebesar 1.97681. jika nilai T hitung lebih besar dari nilai $\mathrm{T}$ tabel maka variabel independen memiliki pengaruh terhadap variabel dependen secara parsial. Pada variabel keterampilan komunikasi didapatkan nilai T hitung sebesar 3.359, sehingga 3.359 > 1.97681 maka keterampilan berkomunikasi memiliki pengaruh secara parsial terhadap kesiapan kerja siswa. Untuk variabel keterampilan berkolaborasi didapatkan nilai $\mathrm{T}$ hitung sebesar 11.011 sehingga $11.011>1.97681$ maka keterampilan berkolaborasi memiliki pengaruh secara parsial terhadap kesiapan kerja siswa.

\section{PEMBAHASAN}

Proses komunikatif yang efektif harus memiliki rasa terbuka ketika berinteraksi. Kesediaan untuk membuka diri dan menyampaikan informasi jika itu layak diperbincangkan. Komunikasi yang efektif tidak dapat dilakukan ketika dalam suasana yang tidak mendukung. Keadaan yang mendukung pada seseorang dapat menunjukkan bahwa dia ingin memiliki rasa untuk bekerja sama.

Pada uji regresi menunjukkan hasil bahwa keterampilan berkomunikasi memiliki pengaruh secara signifikan terhadap kesiapan kerja siswa sekolah menengah kejuruan. Persentase sumbangan pengaruh variabel keterampilan berkomunikasi terhadap kesiapan kerja sebesar 27,7\%. Berdasarkan hasil analisis tersebut bahwa hasil dari penelitian terdapat kecenderungan semakin tinggi memiliki kemampuan berkomunikasi maka semakin tinggi siswa dalam dalam mempersiapkan untuk bekerja. Penelitian lain yang dilakukan oleh Ashari (2018) menunjukkan bahwa keterampilan berkomunikasi dapat memengaruhi kesiapan kerja seorang siswa. Seorang siswa harus mampu mengembangkan keterampilan ini, dengan semakin meningkatnya keterampilan berkomunikasi seorang siswa akan lebih mudah dalam berinteraksi dengan kondisi yang berbeda-beda dan mampu beradaptasi dengan baik. Peningkatan keterampilan berkomunikasi akan berdampak positif pada peningkatan produktivitas pekerjaan (Sasaki, et al. 2017).

Keterampilan berkolaborasi menjadi salah satu pengaruh tertinggi dalam proses kesiapan kerja, tingginya keterampilan ini akan lebih mempersiapkan siswa dalam proses bekerja sama dengan berbagai kelompok kerja dan individu dalam sebuah perusahaan, pendapat ini terdapat dalam penelitian dari Wijaya et al., (2016). Pada uji regresi mendapatkan hasil bahwa keterampilan berkolaborasi berpengaruh signifikan terhadap kesiapan kerja siswa sekolah menengah kejuruan. Persentase sumbangan pengaruh variabel keterampilan berkomunikasi terhadap kesiapan kerja bernilai sebesar 57.7\%. Kondisi tersebut menunjukkan bahwa dengan adanya keterampilan kolaborasi yang tinggi pada siswa sekolah menengah kejuruan, maka kesiapan kerja siswa dalam menghadapi industri yang akan dipilih semakin maksimal.

Dengan adanya proses kolaborasi akan menciptakan kebersamaan, rasa memiliki, tanggung jawab, dan kepedulian antar anggota. Proses berkolaborasi memiliki keuntungan dalam mengembangkan sebuah rencana yang baik. Dengan adanya kolaborasi dapat mencari solusi atau cara dari beberapa orang dengan berbagai macam pemikiran (Nixon, 2014). Dalam proses berkolaborasi harus mampu meredakan egois masing-masing dengan terkontrolnya ambisi besar maka akan dapat menghasilkan rencana yang baik. Keuntungan lain pada proses berkolaborasi adalah dapat menyatukan pengalaman dan ide yang berbeda, hal itu dapat menguntungkan pada rencana yang akan dibuat (Dobos, 2017).

Belum ada penelitian tentang pengaruh keterampilan berkomunikasi dengan keterampilan berkolaborasi siswa SMK terhadap kesiapan kerja secara simultan. Namun, beberapa penelitian yang mengkaji tentang kesiapan kerja siswa yang dipengaruhi oleh keterampilan berkomunikasi dengan variabel lainnya terhadap kesiapan kerja. Namun, pada penelitian ini membuktikan bahwa persentase pengaruh keterampilan berkomunikasi dan keterampilan berkolaborasi terhadap kesiapan kerja secara simultan sebesar $61.1 \%$.

\section{SIMPULAN}

Kesimpulan hasil yang terdapat pada penelitian ini adalah keterampilan berkomunikasi dan keterampilan berkolaborasi berpengaruh secara parsial dan simultan terhadap kesiapan kerja siswa sekolah menengah kejuruan. Hal ini dapat dilihat pada nilai $\mathrm{F}$ hitung bernilai sebesar 110.826, dimana nilai tersebut lebih besar dari F tabel untuk d(f) untuk n sebesar 144 (3.06) dan persentase sumbangan sebesar $61.1 \%$. Dengan memiliki pengaruh yang bersamaan dengan keterampilan tersebut, seorang siswa lebih mampu menghadapi dunia industri dan menjadi seorang pekerja yang profesional dengan soft skill yang dimiliki. Secara parsial atau setiap antar variabel yang tidak bersamaan terhadap kesiapan kerja memiliki pengaruh. Persentase sumbangan keterampilan berkomunikasi terhadap kesiapan kerja sebesar $27.7 \%$ dan sumbangan keterampilan berkolaborasi terhadap kesiapan kerja sebesar $57.7 \%$. Dengan hanya memiliki salah satu keterampilan, seorang siswa mampu mempersiapkan dirinya untuk menjadi seorang pekerja yang profesional di bidangnya atau di luar bidang kejuruannya.

\section{DAFTAR RUJUKAN}

Adu-Oppong., Akua Ahyia., \& Emmanuel Agyin-Birikorang. (2014). Communication In The Workplace: Guidelines for Improving Effectiveness. Global Journal of Commerce \& Management Perspective, 3(5), 208-213.

Alghamdi, A., \& Christian Bach. (2018). Developing Teamwork at Workplace. International Journal of Business and Management Invention, 2(2), 13. 
Alvarez, B., Gillies., \& Bradsher, M. (2003). Secondary Education In The Developing World. P. 112 in Beyond Basic Education. Washington, D.C.: The World Bank.

Aprianto, D., \& Khairrunnisa, U. (2013). Hubungan Sumber Daya Manusia terhadap Tingkat Pendidikan dan Pengangguran Terbuka di Indonesia. Jurnal Elektronik, (5), 398-405.

Ashari, N. P. (2018). Kesiapan Kerja Siswa Ditinjau dari Keterampilan Komunikasi dan Bimbingan Karir pada Siswa Kelas XII Akuntansi di SMK Negeri 6 Sukoharjo. Skripsi tidak diterbitkan. Universitas Muhammadiyah Surakarta, Surakarta.

Barkley, Elizabeth, F., K. Patricia Cross., \& Claire H. Major. (2004). Collaborative Learning Techniques: A Handbook for College Faculty. 1 edition. San Francisco: Jossey-Bass.

Casner-Lotto., Jill., \& Linda Barrington. (2006). Are They Really Ready to Work? Employers' Perspectives on the Basic Knowledge and Applied Skills of New Entrants to the $21^{\text {st }}$ Century U.S. Workforce.” P. 64 in. Washington, D.C.: Partnership for $21^{\text {st }}$ Century Skills.

Harefa, N., \& R. D. Suyanti. (2019). Science Generic Skills of 'Chemistry’? Prospective Teachers: A Study on Collaborative Learning Using Exe-Media. Journal of Physics: Conference Series 1397:012032.

Lower, L. M., Newman, T. J., \& Dawn Anderson-Butcher. (2015). Validity and Reliability of the Teamwork Scale for Youth. Research on Social Work Practice, 27(6), 716-725.

Lukyanova, N., Daneykin, Y., \& Daneikina, N. (2015). Communicative Competence Management Approaches in Higher Education. Procedia - Social and Behavioral Sciences 214, 565-570.

Manyi, T., Sibanda, R., \& Katrodia, A. (2018). The Effect of Using Multi-Skilled Workforce on the Flexibility of Project Resource Scheduling and Project Costs. Journal of Economics and Behavioral Studies, 10(4), 235-251.

Putri, O. R. U., Effendi M. M., \& Slamet, A. (2019). Upaya Peningkatan Soft dan Hard Skill Siswa SMK. Jurnal Pemberdayaan Masyarakat Berkarakter, 2(1), 10.

Reevy, G. M., Chamberlain, C. J., \& Stein, J. (2013). Identifying Collaboration, Teamwork, and Leadership Practices on Campus. Currents in Pharmacy Teaching and Learning, 6(1), 4-17.

Sari, L., Putro, T. S., \& Novalia, L. (2015). Faktor-Faktor yang memengaruhi Tingkat Pengangguran di Kabupaten Kuantan Singingi Provinsi Riau. Jurnal Online Mahasiswa Fakultas Ekonomi Universitas Riau, 2(1), 17.

Sasaki, N., Somemura, H., Nakamura, S., Megumi Yamamoto, Manabu Isojima, Issei Shinmei, Masaru Horikoshi, and Katsutoshi Tanaka. (2017). Effects of Brief Communication Skills Training for Workers Based on the Principles of Cognitive Behavioral Therapy: A Randomized Controlled Trial. Journal of Occupational and Environmental Medicine 59(1), 61-66.

Shahbaz, M., Khan, M. S., Khan, R. M. I., \& Mustafa, G. (2016). Role of Self-Perceived Communication Competence and Communication Apprehension for Willingness to Communicate in L1 and L2. Journal of Educational and Social Research, 6(1), 158.

Sihite, M. (2018). Strategi Membangun Sumber Daya Manusia yang Berdaya Saing Tinggi. STMIK Royal - AMIK Royal, 1(1), $407-412$

Soulé, H., \& Warrick, T. (2015). Defining $21^{\text {st }}$ Century Readiness for All Stu dents: What We Know and How to Get There.” Psychology of Aesthetics, Creativity, and the Arts, 9(2), 178-86.

Titin. (2016). Efisiensi Angka Pengangguran melalui Lulusan SMK dengan Sistem Pendidikan Berkarakter (Enabler, Builders dan Engineer) di Jawa Timur. Jurnal Ekbis: Analisis, Prediksi, dan Informasi, 15(1), 795-805.

Turistiati, A. T., \& Ramadhan, H. F. A. (2019). Pelatihan Soft Skills dan Pendampingan Siswa-Siswi SMK di Kota Bogor untuk Persiapan Memasuki Dunia Kerja. Jurnal Komunitas: Jurnal Pengabdian Kepada Masyarakat, 1(2), 1-8.

Wahyuni, L. M., I. K. Masih, \& I. N. Mei Rejeki. (2018). Communication Skill Attributes Needed for Vocational Education Enter The Workplace. Journal of Physics: Conference Series 953:012111.

Walker, A., Kate M. Storey., Beth M. Costa., \& Rachel K. Leung. (2015). Refinement and Validation of the Work Readiness Scale for Graduate Nurses. Nursing Outlook, 63(6), 632-638. 